\title{
Poisonous Effects of Carbamate Pesticide Sevin on Histopathological Changes of Channa striata (Bloch, 1793)
}

\author{
S. Suja† and E. Sherly Williams \\ Environmental Sciences, Aquaculture and Fish Biotechnology Unit, Department of Zoology, Fatima Mata National \\ College, Research Centre, University of Kerala, India \\ $\dagger$ Corresponding author: S. Suja; sujasschnr@gmail.com
}

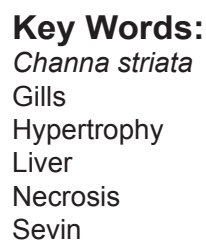

\begin{abstract}
The study was conducted to assess the histopathological impairment of gill and liver of freshwater snakehead murrel, Channa striata. The fish were exposed to sublethal concentrations (1.1 ppm) of insecticide Sevin for 30 days and a parallel control was run simultaneously. No histopathological effects were observed in control. Gill and liver of the exposed fish exhibited some remarkable alterations in their histology. Prominent changes include vacuolation, necrosis, epithelial lifting, shortening of lamellae, the fusion of adjacent lamellae, blood congestion, architectural distortion and degeneration of gills, lamellar fusion, hypertrophy, clubbing, few lamellar missing and shrinkage of blood vessels were observed in treated fishes. Hypertrophy of hepatocytes, necrosis, blood congestion, vacuolation, cellular degeneration, damage of nuclei was observed in the liver of exposed fishes. Duration of exposure of Sevin appears to have a reflective effect on gill and liver as with the increasing duration of exposure histopathological damages become more severe.
\end{abstract}

\section{INTRODUCTION}

The aquatic ecosystems are continuously being contaminated with toxic chemicals from industrial, agricultural and domestic activities. Pesticides are one of the major classes of toxic substances used for management of pests in agricultural lands. It controls pests in crops, but when it reaches the aquatic habitat, affect the nontarget organisms especially fishes. Fishes are particularly sensitive to the pesticidal contamination of water. Hence, these chemical pollutants, when entering into the body of fishes may significantly damage certain physiological and biochemical process and produce serious abnormalities in its organ systems and leads to the extinction of species (Banaee et al. 2011). The carbamate pesticide Sevin is also toxic to nontarget aquatic organisms, especially fishes. Carbamates are reversible inhibitors of the enzyme acetylcholinesterase and they interfere with the cholinergic nervous system and cause death because the effects of the neurotransmitter acetylcholine cannot be terminated by carbamylated acetylcholinesterase (Wang et al. 2012). It is also found to be a neurotoxin (Branch \& Jacqz 1986). The carbamate pesticide, Sevin is known to affect growth, metabolism and development of fish. According to Rani et al. (1990), Sevin is extremely toxic to aquatic and estuarine invertebrates.

The evaluation of pollution effects on various organisms including fish can be studied by using biomarker response.
But most biomarkers are narrow in their expression whereas histopathology is broad in its evaluation (Medja \& Golemi 2011). Histopathological assessments are a suitable tool to evaluate fish stress since they can provide information about chronic and sub-lethal effects of xenobiotics (Raskovic et al. 2013, Traversi et al. 2014). Determination of adverse effects of chemical environmental stressors can be performed by using histopathological analysis in fish, as shown by previous studies (Nunes et al. 2015a,b, Rodrigues et al. 2017a, Limbu et al. 2018). Several types of histological changes have already been reported in fish, due to exposure to various environmental stressors (Lauriano et al. 2012, Mekkawy et al. 2012). Histopathology not only gives an early indication of pollution hazard but also provide useful data on nature and degree of damage to cells and tissues (Shaikh et al. 2010, Malik et al. 2012).

Toxicants are taken up through different organs of fishes because of the affinity between them. Chemical pollutants adversely affect different organs and organ systems. Gills and liver are the common target organs in fish. Gills are the first organ to respond to environmental changes and are involved in respiration, osmoregulation, acid-base regulation, and excretion functions (Raskovic et al. 2010, Rodrigues et al. 2017a). The gills are among the most vulnerable structure of the teleost fish because of their external location and close 
contact with the water. So, they are liable to be damaged by any irritant materials whether dissolved or suspended in the water. According to Takashima \& Hibiya (1995), gills and gastrointestinal tract in fishes considered the main passage for the entrance of pollutants to the internal body.

The liver is a detoxification organ and it is essential for both, the metabolism and the excretion of toxic substances from the fish body (Salamat \& Zarie 2012). According to Mohamed (2009), the liver is also a target organ due to its large blood supply, which causes noticeable toxicant exposure. Moreover, the liver is reported to be the primary organ for bioaccumulation and thus, has been extensively studied in regards to the toxic effects of different xenobiotics (van Dyk et al. 2007, Simonato et al. 2008). The liver is a key organ involved in uptake and accumulation and the defence against toxicants, through metabolism and excretion of toxic substances (Casarett et al. 2008). Also, the incidence of lesions in gills and liver can lead to functional damage, interfering thus directly with fundamental processes for the maintenance of homeostasis in fish. Gills and liver are among the most sensitive organs frequently evaluated as indicators in assessing the health status of fish (Raskovic et al. 2010, Yancheva et al. 2016).

Fishes play significant roles in assessing the potentially toxic effects of aquatic environmental contaminants (Yancheva et al. 2016). A commercially and medicinal important freshwater fish Channa striatus was selected for the present study. Channa striatus (Bloch, 1793), is also known as snakehead murrel. This fish is well- known for its palate, high nutrition, curative and medicinal qualities. According to Mat Jais (1991), murrel flesh has high levels of arachidonic acid which is a precursor for prostaglandin and thromboxin, chemicals that affect blood clotting and the fusion of endothelial tissue in the process of wound healing. In the present study, an effort was made to assess the exposure effect of carbamate pesticide Sevin on the histology of gills and liver of the freshwater fish Channa striatus.

\section{MATERIALS AND METHODS}

The healthy freshwater fish Channa striatus of the weight $(42.26 \pm 0.93 \mathrm{~g})$ and length $(17 \pm 2 \mathrm{~cm})$ were selected for the experiment. These fish were acclimatized under the laboratory conditions for 20 days in an FRP tank filled with dechlorinated water. Water quality characteristics were determined by water quality analyser EUTEC (Cyberscan series 600, Singapore), and are as follows: temperature $27.5 \pm 2.37^{\circ} \mathrm{C}, \mathrm{pH} 7.1 \pm 0.02$, dissolved oxygen $6.2 \pm 0.2$ $\mathrm{mg} / \mathrm{L}$, alkalinity $252 \pm 2.5 \mathrm{mg} / \mathrm{L}$ as $\mathrm{CaCO}_{3}$, total hardness $453 \pm 4.1 \mathrm{mg} / \mathrm{L}$. The fishes were fed daily with minced fish. The test solution was prepared from Sevin, Manufactured by Parikh Enterprises Ltd. The Sevin itself was used as a stock solution. After the preparation of the stock solution, the different concentrations of the test solution were prepared by serially diluting the stock solution. The toxicity tests to calculate LC50 for 96 hours is carried out by the desired concentration of Sevin, prepared by adding the distilled water $(1000 \mathrm{~mL})$. Series of different concentrations $(2,4,6$, 8,10 and $12 \mathrm{ppm}$ ) were prepared. The healthy fishes were selected and tested for 96 hrs. The experiment was started in the morning and behavioural changes were noted. The mortality of fishes was recorded $96 \mathrm{hr}$ LC 50. The LC50 values for different periods were calculated by the method of probit analysis (Finney 1964). Then, fishes exposed in a sub-lethal concentration of Sevin is $1.1 \mathrm{ppm}$. At the end of the experiment, the gill and liver tissue was isolated from control and experimental fishes. The tissue was fixed in aqueous Bouin's solution, processed through graded series of alcohols, cleared in xylene and embedded in paraffin wax. Sections were cut at 3-5 $\mu$ thickness by using Yorco Rotary Microtome, stained with Ehrlich Haematoxylin and Eosin. Slides were observed under the light microscope (Labomed, CXR111) at varying magnifications (10, 40 and 100X) and photographs were taken under a research microscope supported with Q-win software (Leica).

\section{RESULTS AND DISCUSSION}

\section{Gills under Control Condition}

Histological observation of gills from control fish showed normal architecture. The structural particulars of the gill of control C. Striatus are shown in Figs. 1A \& 1B. Structurally, the gills are situated in the branchial chamber on either side of the body in fishes. The gill has a gill arch with a double row of elongated laterally projecting gill filaments. These filaments are flat and leaf-like and join at the base on gill rackers by a gill septum. Numerous semicircular, leaf-like projections are lined up along both sides of the primary gill lamellae called as secondary gill lamellae, which consist of centrally placed rod-like supporting axis with blood vessels on either side. Each of these primary lamellae was flat leaf-like structure and has a series of secondary lamellae located to the primary lamellae with the central supporting axis. The gill is composed of many gill filaments which have primary gill lamellae and secondary gill lamellae that run perpendicular to each filament (Fig. 1A). The secondary lamellae also term as respiratory lamellae are highly vascularized and covered with a thin layer of epithelial cells. Blood vessels are extended into each of the secondary gill filaments provided with pillar and chloride cells. The secondary lamella is supplied with marginal blood sinus lined by endothelium. In between the secondary gill 
lamellae and the primary filament, lined by a thick stratified epithelium. This region between the two adjacent secondary gill lamellae is known as the interlamellar region. The gill arch is a bony structure from which radiate double rows of paired filaments. The lamellae are lined by a squamous epithelium composed by pavement and non-differentiated epithelial cells. Each lamella is made up of two sheets of epithelium bordered by many pillar cells which are contractile and separate the blood channels in which erythrocytes are usually recognized within each capillary lumen. Between the lamellae, the filament is lined by a thick stratified epithelium constituted by several cellular forms, such as chloride cell, mucous or goblet cells.
Mucous cells and chloride cells are also existing in the epithelium of the filament and at the base of lamellae. Gills have an extensive surface area and minimal diffusion distance between dissolved oxygen and blood capillaries for efficient gaseous exchange. However, fish gills are equipped with a defence mechanism working against the environmental irritants which essentially is the mucus cell. The mucus cells react instantaneously to head is covered over by a thick tissue composed of mucus glands, taste buds, and connective tissue. The gill head contains bony part of gill arch and gill rackers. The epithelium surface of the gill arch showing the parallel arrangement of epithelial cells having mucus pores (Fig. 1B)

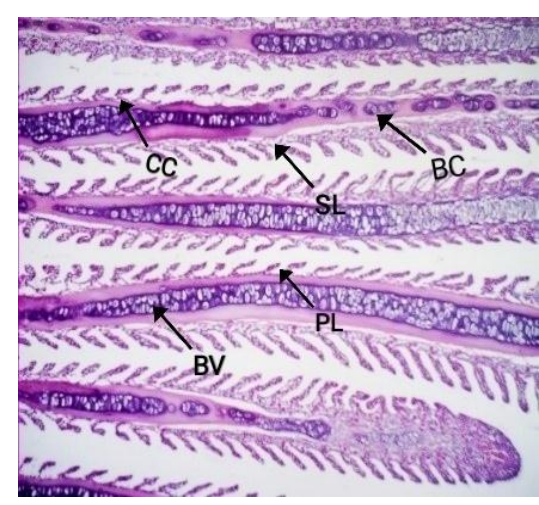

A

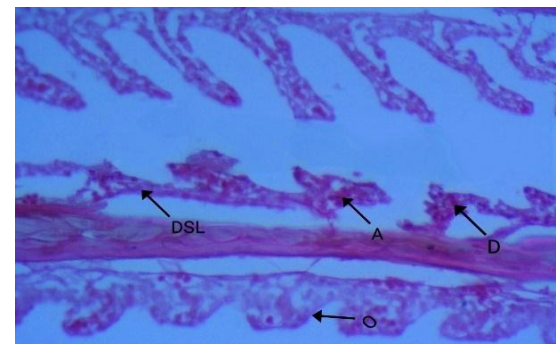

C



E

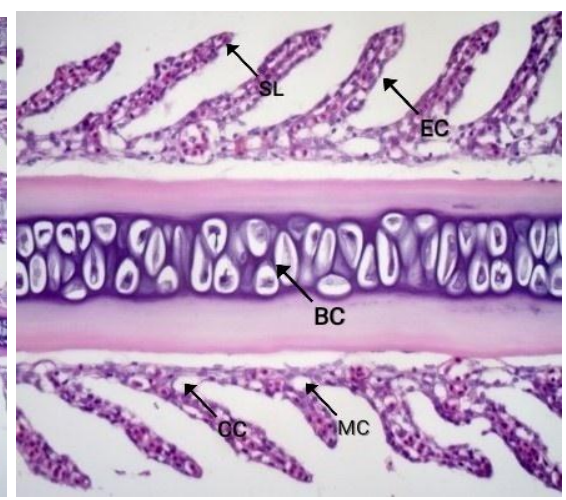

B

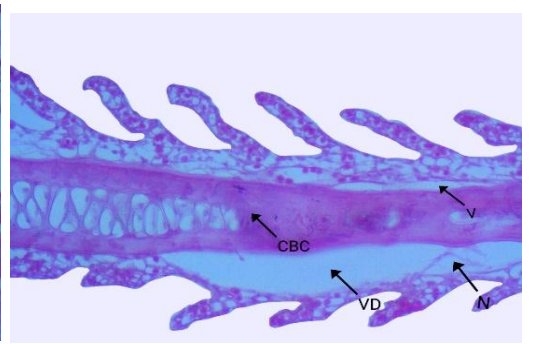

D

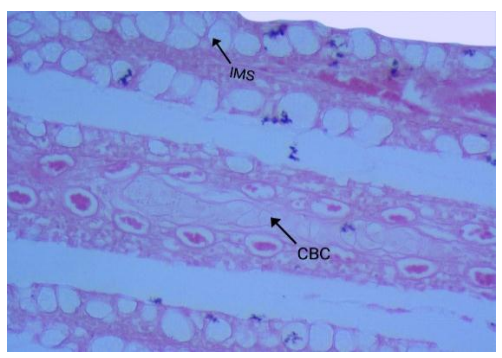

F

Fig. 1: Gill tissue of C. striata: A \& B Control- PL- Primary Lamellae, SL- Secondary Lamellae, Chloride Cell, Mucous Cell, Blood Cells, Blood Vessels, EEpithelial Cells (H\&E, 10 and 40X). (B, C, D, E and F) exposed to 1.1 ppm of Sevin V- Vacoules, H- Hypertrophy, DSL- Distorted Secondary Lamellae, Aneurism, O- Oedema, CBC- Congested Blood Cells, VD- Vasodialation, D- Desquamation, EH- Epithelial Hypertrophy, IMC- Increased Mucous Cells (H\&E, 40X). 


\section{Histopathology of Gills Treated with Sevin}

At a sublethal concentration of Sevin $1.1 \mathrm{ppm}$ for 30 days, the gill tissues of Channa striatus revealed large interlamellar space, necrosis, lamellar fusions enlarged secondary gill lamellae, curved secondary gill filaments resulting in distension of the lamellae. Distorted, swelling of the tip of secondary gill lamellae and the erosion was observed (Fig. 1C and D). A large number of blood cells accumulated in secondary gill lamellae and resulted in the enlargement of gill lamellae, the fusion of secondary gill lamellae was also observed in some areas, epithelial hyperplasia, swelling of epithelial cells and bronchial epithelium disorganization were evident. Furthermore, the epithelial layer detached completely from the central portion of the gill lamellae. epithelial lifting, cell swellings congestions, the bending of secondary lamellae, the formation of edematous space between the layers of epithelium which may become infiltrated with red blood cells. Gill hyperplasia was observed in the primary epithelial cells. Then, the whole lamellar epithelium was found to be degeneration (Fig.1. E and F).

Sevin is considered as a highly toxic pesticide to freshwater organisms. The present study was in agreement with similar observations reported under Sevin toxicity at $96 \mathrm{hr}$ in the freshwater fish, Channa punctatus (Deepasree \& Nair 2015). Degenerative epithelium of gill filaments and secondary lamellae accompanied by separation of their epithelium from the lamellar supporting cells was also demonstrated in the experiment of Bhuvaneshwari et al. (2015) on Zebrafish exposed to organochlorine pesticide and heavy metals. Dilation of blood capillaries, abnormal swellings epithelium was observed by Banae et al. (2013) in Rainbow trout exposed to pesticide diazinon.

There are several reports on various histological changes in fish gills, acute or chronic exposure with sublethal toxicant concentrations (Velcheva et al. 2010a\&b, Muthukumaravel et al. 2013, Sousa et al. 2013 a\&b, Khatun et al. 2016). According to Camargo \& Martinez (2007), Ayandiran et al. (2009) and Vigario \& Saboia-Morais (2014) the toxicants could induce gill histological alterations such as epithelium degeneration and necrosis, which means fish can develop numerous defence mechanisms, which could prevent the toxicant negative effects. These mechanisms are expressed in different morphological changes including oedema, the proliferation of epithelium and fusion.

Epithelium lifting was observed in the Sevin treated gills. Epithelial lifting increases the distance between the blood and epithelial layer and thus decrease the velocity of penetration of the molecules of Sevin into the blood. So, the epithelial lifting can be considered as a defence mechanism adopted by fishes to slow down the penetration of pesticide through the lamellar epithelium. The epithelial lifting in gills decelerate oxygen uptake and produce dysfunctional gills, and eventually asphyxiate the fish (Kumar et al. 2010).

Gill lesions associated with the lamellar aneurysm were observed in prevalence in all treatment groups. The lesions may be due to the disturbance of blood flow in the blood channels. Similar histopathological lesions have been reported by (Devi \& Mishra 2013) chlorpyrifos exposed in Channa punctatus.

\section{Liver under Control Condition}

The liver is the organ which is most associated with the detoxification and biomarker process. Due to its function, position and blood supply, it is also one of the most affected organs by contaminants in water (Camargo \& Martinez 2007). Histological observation of liver from control fish in the present study showed normal architecture. The liver of untreated fish was exhibited parenchymatous appearance and mainly consisted of polygonal-shaped hepatocytes with their central nuclei. Sinusoids are irregularly distributed between the polygonal hepatocytes. Hepatopancreatic alveoli of the exocrine pancreas were seen to be placed in the parenchyma and the melanomacrophages centre stained light brown were located close to the hepatopancreas. Some of the hepatocyte nearby the hepatopancreas was slightly vacuolated it could be due to storage of glycogen and lipid (Fig. 2A \& B).

\section{Histopathology of the Liver Treated with Sevin}

In sublethal concentration, $1.1 \mathrm{ppm}$ of Sevin to Channa striatus, showed congestion of central vein, degeneration of hepatocytes, cytoplasmic vacuolization and a large number of distorted hepatocytes. The liver treated with a high dose of Sevin showed centrilobular necrosis characterized by necrosis of hepatocytes around the congested central vein. Hepatocytes showed increased granularity of cytoplasm with nuclear pyknosis leading to necrosis and complete loss of hepatic parenchyma (Fig. $2 \mathrm{C})$. The liver of fishes treated with a low concentration of Sevin was reflected by disorganization of hepatic cords, degeneration, hepatic hypertrophy, focal necrosis with complete loss of hepatocytes at many places (Fig. 2D).

In fish, the liver is the main organ that plays an important role in the detoxification of chemicals and pesticides. During metabolism, the liver helps to break down the harmful substances, but beyond a certain limit, these toxic compounds distract the regulating mechanism of the liver and cause morphological alteration (Brusle et al. 1996). The fatty infiltration, hemosiderosis and congested central vein, se- 


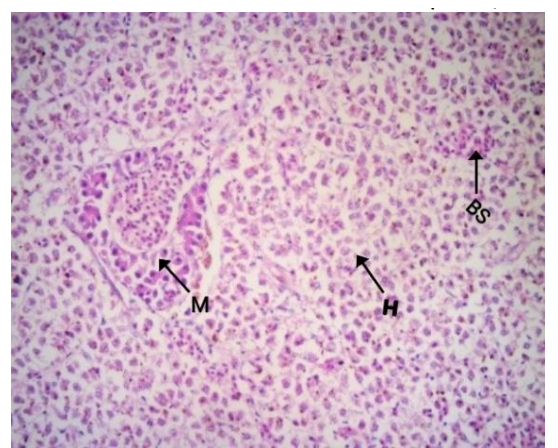

A

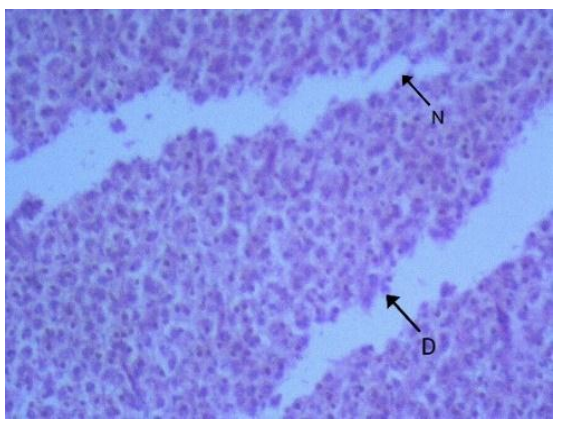

C

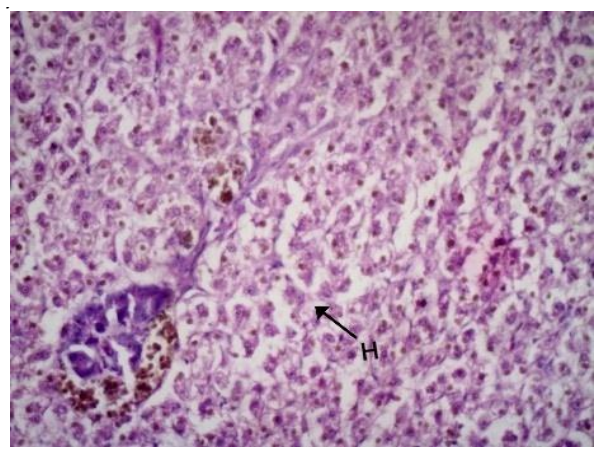

B

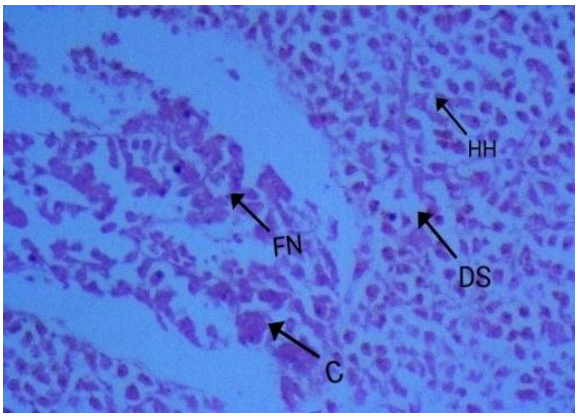

$\mathrm{D}$

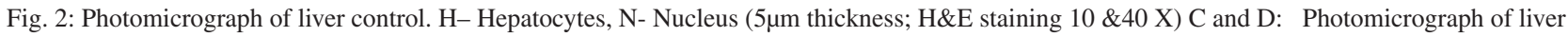
of fish exposed to Sevin. DH- Degradation of cellular hepatocytes, DS-Distortion, H- hypertrophy, N-Necrosis, C- Congestion, FN- Focal necrosis, HH- Hypertrophy of Hepatocytes (5 $\mu$ m thick; H\&E staining; 10X and 40X).

vere necrosis, haemorrhage, vacuolation, severe infiltration of leukocytes, pyknotic and hepatic necrosis in the liver of the fish Clarias gariepinus after exposing to lethal concentrations of cypermethrin were observed by Ayoola \& Ajani (2008); present result agrees with this result. The infiltration of fatty molecules and vacuolization in the liver specify the accumulation of fat and disparity between the rate of synthesis and release of a substance in hepatocytes (Gingerich 1982), whereas necrosis in some part of liver may appear due to extra workload on hepatocyte during detoxification (Petal \& Bahadur 2011). Focal necrosis is probably due to the involvement of liver cells in the metabolic transformation of the insecticide, causing functional and structural changes to the cells (De Melo et al. 2008). Histological changes associated with different pesticides in freshwater fish have been studied by many authors Clarius gariepinus (Ayoola \& Ajani 2008); Oreochromis mossambicus (Navaraj \& Yasmin 2012); Channa punctatus (Magar \& Shaikh 2013); Labeo rohita (Nagaraju \& Rathnamma 2014); Cyprinus carpio (Chamarthi et al. 2014); Channa gachua (Rai \& Mishra 2014, Kadam \& Patil 2018); Heteropneustes fossilis (Pandey \& Dubey, 2015); Cyprinus carpio (Lakshmaiah 2016) and Trichogaster fasciata (Mukti 2018).
Thus, the histological changes that were taking place in the present study, as the initial period of exposure in the organs of the fish on exposure to Sevin toxicity might be a part of the defence mechanism. The further accumulation of Sevin in the organs of the fish on continued exposure destroyed the organ structures. The slight structural reorganization of the gill and liver of the fish observed at day 30 of exposure to Sevin toxicity gives support to some extent that the ability of the fish to resist the sublethal stress and in the repair of the damage caused to the organ by enhancing the protein synthetic potentials and other associated activities of the cell.

\section{CONCLUSION}

Pesticide toxicant leads to many pathological changes in different tissues of fish exposed to Sevin. The increasing amounts of carbamate pesticide Sevin incoming to aquatic bodies can result in the amount of accumulation of contaminants increased in the fish and their consumers, which create a serious hazard to ecosystems. In the last decades, the fast growth of industry and agriculture has resulted in increased pesticides pollution, which is a significant environmental hazard for invertebrates, fish, and humans. 


\section{ACKNOWLEDGMENT}

The corresponding author is grateful to RGNF for financial assistance in the form of JRF. The facilities provided by the Research Department of Zoology, Fatima Mata National College, Kollam are greatly acknowledged.

\section{REFERENCES}

Ayandiran, T.A., Fawole, O.O., Adewoye, S.O. and Ogundiran, M.A. 2009. Bioconcentration of metals in the body muscle and gut of Clarias gariepinus exposed to sublethal concentrations of soap and detergent effluent. Journal of Cell and Animal Biology, 3: 113-118.

Ayoola, S.O. and Ajani, E.K. 2008. Histopathological effects of cypermethrin on juvenile African catfish (Clarias gariepinus). World Journal of Biological Research, 1(2): 1-14.

Banaee, M., Mirvaghefei, A.R., Majazi-Amiri B., Rafei, G.R. and Nematdost, B. 2011. Hematological and histopathological study of experimental diazinon poisoning in common carp fish (Cyprinus carpio). J. Fish. Iran. J. Nat. Res., 64: 1-14.

Banaee, M., Sureda, A., Mirvagefei, A.R. and Ahmadi, K. 2013. Histopathological alterations induced by diazinon in rainbow trout (Oncorhynchus mykiss). International Journal of Environmental Research, 7(3): 735-744.

Bhuvaneshwari, R., Padmanabhan, K. and Babu Rajendran, R. 2015. Histopathological alterations in muscle, liver and gill tissues of Zebra fish Danio Rerio due to environmentally relevant concentrations of organochlorine pesticides and heavy metals. Int. J. Environ. Res., 9(4): 1365-1372.

Bloch, M. E. 1793. Naturgeschichte der auslandischen fische. 7, Berlin, Germany, Morino and Co. 7, 1-xiv+1. 44: 325-360.

Branch, R.A and Jacqz. E. 1986. Subacute neurotoxicity following longterm exposure to carbaryl. Am. J. Med., 80: 741-745.

Brusle, J., Gonzalez, I. and Anadon, G. 1996. The structure and function of fish liver. In: Munshi, J.S.D. and Dutta (Ed.) Fish Morphology. Science Publishers, New York, USA.

Camargo, M.M.P. and Martinez, C.B.R. 2007. Histopathology of gills, kidney and liver of a Neotropical fish caged in an urban stream. Neotropical Ichthyology, 5(3): 327-336.

Casarett, L.J., Klaassen, C.D., Amdur, M.O and Doull, J. 2008. Toxicology: The Basic Science of Poisons, 7th Edn. McGraw-Hill, Health Professions Division, New York, pp. 557-551.

Chamarthi, R.R., Bangeppagari, M., Gooty, J. M., Mandala, S., Tirado, J. O. and Marigoudar, S.R. 2014. Histopathological alterations in the gill, liver and brain of Cyprinus carpio on exposure to quinalphos. American Journal of Life Sciences, 2(4): 211-216.

Costa, P.M., Diniz, M.S., Caeiro, S., Lobo, J., Martins, M., Ferreira, A.M, Caetano, M., Vale, C., DelValls, T.A and Costa, M.H. 2009. Histological biomarkers in liver and gills of juvenile Solea senegalensis exposed to contaminated estuarine sediments: A weighted indices approach. Aquat. Toxicol., 92: 202-212.

De Melo, G., Donattib, L., Rudnikia, C. and Fanta, E. 2008. Hepatic alterations in the fish Rhamdia quelen contaminated with Folidol 600®. Ecotoxicol. Environ. Saf., 71: 821-829.

Deepasree, M.I and Rajendran Nair, M. S. 2013. Histological and ultrastructural alterations of gills of freshwater fish Channa punctatus (Bloch), on exposure to pesticide, Sevin. International Journal of Science and Research, 5(6): 991-995.

Devi, Y. and Mishra, A. 2013. Histopathological Alterations in gill and liver anatomy of freshwater, air breathing fish Channa punctatus after pesticide Hilban (Chlorpyrifos) Treatment. Adv Biores., 2: 57- 62.
Finney, D.J. 1971. Probit Analysis, University Press, Cambridge, pp. 333. Gingerich, W.H. 1982. Hepatic toxicology of fishes. In: Aquatic Toxicology, pp. 55-105.

Kadam, P.L. and Patil, R.N.2018. Histopathological alterations produced in the liver of snake head fish, Channa gachua (F. Hamilton) exposed to dichlorvos. Bioscience Discovery, 9(1): 08-14.

Khatun, N., Rahman, T. and Mahanta, R. 2016. Histopathological studies of chlorpyrifos toxicity in catfish. Global Journal of Medical Research and Pathology, 16(3): 49-54.

Kumar, M., Prasad, M.R., Srivastava, K., Tripathi, S. and Srivastav, A.K. 2010. Branchial histopathological study of Catfish Heteropneustes fossilis following exposure to purified neem extract, Azadirachtin. World Journal of Zoology, 5(4): 239-243.

Kunjamma, A., Philip, B., Bhanu, S. and Jose, J. 2008. Histopathological effects on Oreochromis mossambicus (Tilapia) exposed to chlorpyrifos. Journal of Environmental Research and Development, 2(4): 553-559.

Lakshmaiah, G. 2016. A histopathological study on the liver of common carp Cyprinus carpio exposed to sublethal concentrations of phorate. International Journal of Applied Research, 2(6):96-100 .

Lauriano, E.R., Calo, M., Silvestri, G., Zaccone, D., Pergolizzi, S. and Cascio, P.L. 2012. Mast cells in the intestine and gills of the sea bream, Sparus aurata, exposed to a polychlorinated biphenyl, 126. Acta. Histochem., 114(2): 166-171.

Limbu, S. M., Zhou, L., Sun, S. X., Zhang, M. L and Du, Z. Y. 2018. Chronic exposure to low environmental concentrations and legal aquaculture doses of antibiotics cause systemic adverse effects in Nile tilapia and provoke differential human health risk. Environ. Int., 115: 205-219.

Magar, R.S. and Afsar Shaikh 2013. Effect of malathion toxicity on detoxifying organ of freshwater fish Channa punctatus. International Journal of Pharmaceutical, Chemical and Biological Sciences. 3(3): 723-728.

Malik, G. M., Raval, H. V. and Ahmed Khali, H.K. 2012. Toxic effects of effluent on mortality and behavior changes on freshwater fish Poecilia reticulate. Environ. Res. Develop., 7(2A): 1036-1039.

Mat Jais, A.M. 1991. Haruan, Channa striatus, farming in backyard. Proceedings of the Third Asian Conference of Technology for Rural Development. 91: 230-232.

Medja, N. and Golemi, S. 2011. Histopathology of larva Carassius gebelio biomarker of pollution with cyanobacteria of Shkodra lake water, Albania. Journal of Environmental Research and Development, 6(2): 281-285.

Mekkawy, I.A.A., Mahmoud, U.M., Wassif, E.T and Naguib, M. 2012. Protective roles of tomato paste and vitamin E on cadmium-induced histological and histochemical changes of liver of Oreochromis niloticus (Linnaeus, 1758). J. Fisher. Aqua.Sci. 7: 240-265.

Mohamed, F.A.S. 2009. Histopathological studies on Tilapia zillii and Solea vulgaris from Lake Qarun, Egypt. World J. Fish Mar. Sci., 1(1): 29-32.

Mukti, S.S., Ahmed, G.U., Ahmed, Z.F., Sumon, K.A. and Fatema, M.K. 2018. Histopathological study of female striped Gourami

(Trichogaster fasciata), Bloch and Schneider, 1801) gill exposed to chlorpyrifos. International Journal of Aquaculture, 8(14): 104-111.

Muthukumaravel, K., Sathick, O. and Raveendran, S. 2013. Lambda cyhalothrin induced biochemical and histological changesintheliver of Oreochromis mossambicus (Peters). Int. J. Pure Appl. Zool., 1(1): 80-85.

Nagaraju, B. and Rathnamma, V. 2014. Effect of profenofos and organophosphate on protein levels in some tissues of freshwater fish Labeo rohita (Hamilton). International Journal of Pharmacy and Pharmaceutical Sciences, 5(1): 276-279.

Navaraj, P.S. and Yasmin, J. 2012. Histopathological impact of industrial wastewater on the vital organs of Oreochromis mossambicus. Toxicological and Environmental Chemistry, 94(3): 574-582. 
Nunes, B., Antunes, S.C., Gomes, R., Campos, J.C., Braga, M.R., Ramos, A.S and Correia, A.T. 2015a. Acute effects of tetracycline exposure in the freshwater fish Gambusia holbrooki: Antioxidant effects, neurotoxicity and histological alterations. Arch. Environ. Contam. Toxicol., 68: 371-381.

Nunes, B., Campos, J.C., Gomes, R., Braga, M.R., Ramos, A.S., Antunes, S.C and Correia, A.T. 2015b. Ecotoxicological effects of salicylic acid in the freshwater fish Salmo truttafario: Antioxidant mechanisms and histological alterations. Environ. Sci. Pollut. Res., 22(1): 667-678.

Pandey, A.K and Dubey, S. 2015. Histological changes in liver and kidney of catfish, Heteropneustes fossilis, exposed to pentachlorophenol (PCP). Plant Archives, 15(2): 1117-1120.

Petal, J.M. and Bahadur, A. 2011. Histopathological alterations in Catla catla induced by chronic exposure of copper ions. J. Cell. Tissue.Res., 10: 2365-2370.

Rai, M.K. and Mishra, A.P. 2014. Histopathological alteration in gill of Channa gachua exposed to an organophosphate. The Asian Journal of Animal Science, 9(2): 169-173.

Rani, S., Shaik Dawood, A. and Ramasamy, M. 1990. Toxicity of a carbamate fungicide, cuman to an edible, freshwater fish, Sarotherodon mossambicus (Peters). J. Aquor., 3(1): 29-36.

Raskovic, B., Jaric, I., Koko, V., Spasic, M., Dulic, Z., Markovic, Z. and Poleksic, V. 2013. Histopathological indicators: A useful fish health monitoring tool in common carp (Cyprinus carpio: Linnaeus, 1758) culture. Cent. Eur. J. Biol., 8(10): 975-985.

Raskovic, B., Poleksic, V., Zivic, I. and Spasic, M. 2010. Histology of carp (Cyprinus carpio L.) gills and pond water quality in semi intensive production. Bulg. J. Agric. Sci., 16(3): 253-262.

Raskovic, B., Poleksic, V., Zivic, I. and Space, M. 2010. Histology of carp (Cyprinus carpio, L.) gills and pond water quality in semi intensive production. Bulg. J. Agric. Sci., 16: 253-262.

Rodrigues, S., Antunes, S.C., Correia, A.T. and Nunes, B. 2017b. Rainbow trout (Oncorhynchus mykiss) pro-oxidant and genotoxic responses following acute and chronic exposure to the antibiotic oxytetracycline. Ecotoxicology, 26: 104-117.

Rodrigues, S., Antunes, S.C., Nunes, B. and Correia, A.T. 2017a. Histological alterations in gills and liver of rainbow trout (Oncorhynchus mykiss) after exposure to the antibiotic oxytetracycline. Environ. Toxicol. Pharmacol., 53: 164-176.

Salamat, N. and Zarie, M. 2012. Using of fish pathological alterations to assess aquatic pollution- A review. World Journal of Fish and Marine Sciences, 4(3): 223-231.
Shaikh, F. I., Ustad, I. R. and Ansari, N.T. 2010. Effect of heavy metal on the ovary of freshwater crab Barylelphusa cunicularis. The Bioscan, 5(2): 335-338.

Simonato, J.D., Guedes, C.L.B., Martinez, C.B.R. 2008. Biochemical, physiological, and histological changes in the neotropical fish Prochilodus lineatus exposed to diesel oil. Ecotoxicology and Environmental Safety, 69(1): 112-120.

Sousa, D.B.P., Almeida, Z.S. and Carvalho-Neta, R.N.F. 2013b. Integrated analysis of two biomarkers in Sciades herzbergii (Ariidae, Siluriformes), to assess the environmental impact at São Marcos. Latin American Journal of Aquatic Research, 45: 305-312.

Sousa, D.B.P., Almeida, Z.S. and Carvalho-Neta, R.N.F. 2013a. Histology biomarkers in two estuarine catfish species from the Maranhense coast. Arquivo Brasileiro de Medicina Veterinaria Zootecnia, 65(2): 369-376.

Takashima, F. and Hibiya, T. 1995. An Atlas of Fish Histology. Normal and Pathological Features. $2^{\text {nd }}$ ed. Tokyo, Kodansha Ltd., pp. 51.

Traversi, I., Gioacchini, G., Scorolli, A., Mita, D.G., Carnevali, O. and Mandich, A. 2014. Alkyl phenolic contaminants in the diet Sparus aurata juvenile's hepatic response. Gen. Comp. Endocrinol., 205: 185-196.

van Dyk, J.C., Pieterse, G.M., van Vuren, J.H.J. 2007. Histological changes in the liver of Oreochromis mossambicus (Cichlidae) after exposure to cadmium and zinc. Ecotoxicol. Environ. Saf., 66: 432-440.

Velcheva, I., Arnaudov, A. and Georgieva, E. 2010a. Influence of zinc on gill morphology of Gibelio carp Carassius gibelio. Ecologia Balkanica, 2: 19-23.

Velcheva, I., Tomova, E., Arnaudova, D. and Arnaudov, A. 2010 b. Morphological investigation on gills and liver of freshwater fish from dam lake. Bulgarian Journal of Agricultural Science, 16: 364-368.

Vigario, A.F. and Saboia-Morais, S.M.T. 2014. Effects of the 2,4-D herbicide on gills epithelia and a liver of the fish Poecilia vivipara. Pesqisa Veterinaria Brasiliera, 34(6): 523-528.

Wang, J., Chen, F., Zheng, P., W.J., Yuan, J., Peng, B., Wang, R.C., Liu, W.J., Zhao, H. and Wang, Y.Q. 2012. Huperzine a ameliorates experimental autoimmune encephalomyelitis via the suppression of $\mathrm{t}$ cell-mediated neuronal inflammation in $\mathrm{mice}$. Ex p . Neurol., 236: 79-87.

Yancheva, V., Velcheva, I., Stoyanova,s and Georgieva, E. 2016. Histological biomarkers in fish as a tool in ecological risk assessment and monitoring programs: A review. Applied Ecology and Environmental Research, 14(1): 47-75. 